\title{
Kesehatan Telinga di Sekolah Dasar Negeri 11 Manado
}

\author{
${ }^{1}$ Amelia M. Korompis \\ ${ }^{2}$ R. E. C. Tumbel \\ ${ }^{2}$ Steward K. Mengko
}

\author{
${ }^{1}$ Program Studi Pendidikan Dokter Fakultas Kedokteran Universitas Sam Ratulangi Manado \\ ${ }^{2}$ Bagian/SMF Telinga Hidung Tenggorok-Bedah Kepala Leher Fakultas Kedokteran \\ Universitas Sam Ratulangi Manado \\ Email: amelia.korompis@yahoo.com
}

\begin{abstract}
Ear is one of the sense organs in human that can absorb $20 \%$ of information in daily life. This study was aimed to obtain the ear health status of students in SD Negeri 11 (elementary school) Manado. This was an observational descriptive study with a cross sectional design. The ear health was determined by examination of outer ear (auricle), middle ear (ear canal), and tympanic membrane. There were 25 subjetcts in this study. The examination of auricle resulted in all subjects $(100 \%)$ had normal auricle. The examination of ear canal obtained 17 subjects (68\%) had normal ear canal. Cerumen was found in right ear canal of 3 subjects (12\%) and in left ear canal of 5 subjects $(20 \%)$. The examination of tympanic membrane showed all students $(100 \%)$ had normal membrane. Conclusion: Most students of SD Negeri 11 Manado had good ear health status.
\end{abstract}

Keywords: ear health

\begin{abstract}
Abstrak: Telinga merupakan salah satu alat indra penting yang dapat menyerap sebesar $20 \%$ informasi dari kehidupan sehari-hari. Penelitian ini bertujuan untuk mendapatkan gambaran kesehatan telinga pada siswa SD Negeri 11 Manado. Jenis penelitian ialah deskriptif observasional dengan desain potong lintang. Gambaran kesehatan telinga dilihat dengan memeriksa daun telinga, liang telinga, dan membran timpani. Hasil penelitian mendapatkan sebanyak 25 subyek penelitian. Pemeriksaan daun telinga mendapatkan semuanya normal (100\%). Pemeriksaan liang telinga dengan hasil normal didapatkan pada 17 subyek (68\%). Serumen didapatkan dalam liang telinga kanan pada 3 subyek (12\%) dan telinga kiri pada 5 subyek (20\%). Pemeriksaan membran timpani mendapatkan hasil normal pada semua subyek (100\%). Simpulan: Sebagian besar siswa SD Negeri 11 Manado memiliki status kesehatan telinga yang baik.
\end{abstract}

Kata kunci: kesehatan telinga

Telinga adalah salah satu alat indra yang penting dan berperan besar dalam kehidupan sehari-hari. Jika terdapat gangguan pada telinga maka proses penerimaan informasi akan terganggu. ${ }^{1}$ Menurut World Health Organization (WHO), diperkirakan terdapat 360 juta $(5.3 \%)$ orang di dunia mengalami gangguan pendengaran; 328 juta $(91 \%)$ di antaranya ialah orang dewasa (183 juta laki-laki dan 145 juta perempuan) dan 32 juta (9\%) anak-anak. Prevalensi gangguan meningkat seiring dengan pertambahan usia. Prevalensi gangguan pendengaran pada orang di atas usia 65 tahun bervariasi dari $18-50 \%$ di seluruh dunia. $^{2}$

Peningkatan kualitas hidup anak ditentukan oleh penanaman perilaku kesehatan anak sejak dini. Perilaku anak sekolah sangat bervariasi dan bila tidak dikenali dan ditangani sejak dini, gangguan kesehatan ini akan memengaruhi prestasi 
belajar dan masa depan anak. Salah satu bentuk perilaku kesehatan yang perlu mendapat perhatian ialah kebersihan telinga. ${ }^{3,4}$

Hasil skrining kesehatan telinga dan pendengaran yang dilakukan pada sejumlah siswa sekolah dasar di Desa Sebani. Kabupaten Jombang menunjukkan dari 143 siswa, 50\% diantaranya mengalami penyakit telinga dan gangguan pendengaran serta 93\% diantaranya mengaku tidak pernah memeriksakan kondisi kesehatan telinga. ${ }^{5}$

SD Negeri 11 Manado adalah sekolah dasar yang terletak di pusat kota Manado. Kegiatan sekolahnya sama seperti anakanak SD pada umumnya, yakni belajar dan menerima pelajaran. Penelitian ini bertujuan untuk mengetahui gambaran kesehatan telinga pada anak-anak Sekolah Dasar Negeri 11 Manado.

\section{METODE PENELITIAN}

Jenis penelitian ini ialah deskriptif observasional, dengan desain potong lintang. Penelitian ini dilaksanakan di SD Negeri 11 Manado pada bulan Oktober 2015. Populasi ialah siswa SD Negeri 11 Manado dengan subyek penelitian ialah siswa kelas 6 SD Negeri 11 Manado.

Pengambilan data penelitian dilakukan melalui wawancara dan pemeriksaan meatus austikus eksternus dengan menggunakan alat seperti lampu kepala, spekulum telinga, dan otoskop. Pada pemeriksaan dinilai gangguan/kelainan pada daun telinga, liang telinga dan membran timpani.

\section{HASIL PENELITIAN}

Subyek penelitian berjumlah 25 siswa yang bersia 9-11 tahun, terdiri dari 11 siswa perempuan (44\%) dan 14 siswa lakilaki $(56 \%)$. Pada pemeriksaan daun telinga siswa SD Negeri 11 Manado didapatkan semuanya normal; tidak didapatkan hasil yang abnormal.

Pada pemeriksaan liang telinga siswa SD Negeri 11 Manado didapatkan serumen dalam liang telinga kanan pada 3 anak (12\%) dan telinga kiri 5 anak (20\%); sebanyak 17 anak (68\%) normal. Tidak di temukan kelainan seperti hiperemis, sekret, debris, furunkel, atau udim (Tabel 1).

Tabel 1. Distribusi berdasarkan keadaan liang telinga

\begin{tabular}{ccccc}
\hline Keadaan & \multicolumn{2}{c}{$\mathbf{N}$} & \multicolumn{2}{c}{$\%$} \\
\cline { 2 - 5 } $\begin{array}{c}\text { liang } \\
\text { telinga }\end{array}$ & Kanan & Kiri & Kanan & Kiri \\
\hline Normal & 17 & 17 & $68 \%$ & $68 \%$ \\
Hiperemis & 0 & 0 & 0 & 0 \\
Serumen & 3 & 5 & $12 \%$ & $20 \%$ \\
Sekret & 0 & 0 & 0 & 0 \\
Debris & 0 & 0 & 0 & 0 \\
Furunkel & 0 & 0 & 0 & 0 \\
Udim & 0 & 0 & 0 & 0 \\
Total & 25 & \multicolumn{2}{c}{$100 \%$} \\
\hline
\end{tabular}

Pada pemeriksaan membran timpani siswa SD Negeri 11 Manado didapatkan hasil normal pada semua siswa-siswi yaitu sebanyak 25 anak (100\%). Dalam pemeriksaan ini tidak didapatkan kelainan seperti perforasi, retraksi, bombans, suram, mapun hiperemis (Tabel 2).

Tabel 2. Keadaan membran timpani

\begin{tabular}{ccccc}
\hline Keadaan & \multicolumn{2}{c}{$\mathbf{N}$} & \multicolumn{2}{c}{$\%$} \\
\cline { 2 - 5 } $\begin{array}{c}\text { membran } \\
\text { timpani }\end{array}$ & Kanan & Kiri & Kanan & Kiri \\
\hline Normal & 25 & 25 & $100 \%$ & $100 \%$ \\
Perforasi & 0 & 0 & 0 & 0 \\
Retraksi & 0 & 0 & 0 & 0 \\
Bombans & 0 & 0 & 0 & 0 \\
Suram & 0 & 0 & 0 & 0 \\
Hiperemis & 0 & 0 & 0 & 0 \\
Total & 35 & \multicolumn{2}{c}{$100 \%$} \\
\hline
\end{tabular}

\section{BAHASAN}

Pada penelitian terhadap siswa SD Negeri 11 Manado ini subyek yang bersedia mengikuti penelitian sebanyak 25 siswa. Berdasarkan karakteristik jenis kelamin subyek penelitian terdiri atas 11 orang laki-laki $(44 \%)$ dan 14 orang perempuan (56\%). Karakteristik usia terbanyak pada subyek penelitian ialah 10 tahun (50\%).

Berdasarkan hasil pemeriksaan daun telinga kanan dan kiri, sernua subyek baik perempuan maupun laki-laki memper- 
lihatkan hasil lapang dengan kata lain normal. Abnormalitas pada daun telinga dapat disebabkan oleh banyak penyebab, salah satunya kelainan kongenital seperti mikrotia. ${ }^{6-8}$

Pada pemeriksaan liang telinga subyek penelitian didapatkan hasil sebagian besar normal $(68 \%)$. Keadaan abnormal terbanyak yakni serumen yaitu dalam telinga kanan pada 3 subyek (12\%) dan telinga kiri 5 subyek $(20 \%)$. Serumen secara normal dapat ditemukan dalam telinga dan memiliki fungsi proteksi. Serumen ini dapat membentuk massa yang dapat menyumbat liang telinga. Berbagai faktor berkaitan dalam pembentukan serumen yaitu faktor internal seperti kelainan bentuk anatomis hang telinga, sekret serumen berlebihan, kelainan sistemik. ${ }^{6-8}$

Pada pemeriksaan membran timpani kanan dan kiri terhadap semua subyek baik laki-laki maupun perempuan tidak ditemukan adanya kelainan. Beberapa penyebab kelainan pada membran timpani misalnya perforasi membran timpani yaitu hilangnya sebagian jaringan atau seluruh fungsi dari membran timpani.

Pada pemeriksaan kesehatan telinga terhadap semua subyek memperlihatkan hasil normal yang dominan. Kesehatan individu seorang anak dapat dipengaruhi oleh banyak faktor salah satunya faktor internal yakni peran orang tua. ${ }^{6-8}$

\section{SIMPULAN}

Berdasarkan hasil penelitian ini dapat disimpulkan bahwa kesehatan telinga pada siswa kelas 6 SD Negeri 11 Manado menunjukkan sebagian besar normal.

\section{SARAN}

Disarankan untuk melakukan penyuluhan kesehatan telinga, hidung, dan tenggorok yang diolah oleh pemerintah terhadap masyarakat untuk meningkatkan kesehatan hidung, telinga, dan tenggorok terlebih siswa-siswi Sekolah Dasar.

Diharapkan penelitian lanjutan untuk menilai faktor-faktor yang menyebabkan pembentukan serumen, sekret dan perforasi serta cara penanganan yang tepat.
Penderita gangguan telinga yang lebih berat, perlu dilakukan pemeriksaan lebih lanjut di Puskesmas dan Bagian THT-KL Rumah Sakit agar supaya dapat dilakukan pemeriksaan dan pengobatan yang lebih memadai.

Pada penemuan hasil pemeriksaan seperti sekret liang telinga dan adanya perforasi pada membran timpani diperlukan edukasi terhadap orang tua untuk pemeriksaan serta penanganan yang lebih lanjut di fasilitas kesehatan yang lebih lengkap. Juga diperlukan peran serta orangtua dan komunitas dalam pemberian motivasi, pengetahuan perilaku hidup bersih terutama pada kesehatan telinga dan pendengaran.

\section{DAFTAR PUSTAKA}

1. Keputusan Menteri Kesehatan Republik Indonesia No. 879/Menkes/SK/XI/ 2006 tentang rencana strategi nasional penanggulangan gangguan pendengaran dan ketulian untuk mencapai sound hearing 2030.

2. Kementerian Kesehatan Republik Indonesia. Pendengaran Sehat Untuk Hidup Bahagia. 2013 Maret $10 \quad[2015$ September 22]. Available from: http://www.Depkes.Go.Id/Index.Php /Berita/Press-Release/840-TelingaSehatpendengaran- Baik.Html.

3. Probst R, Grevers G, Iro H. Basic Otorhinolaryngology. A Step-by-Step Learning Guide. New York: Thieme, 2006; p. 154,198.

4. Kementerian Kesehatan Republik Indonesia. Telinga Sehat Pendengaran Baik. 2010 Maret 4. [2015 Oct 22]. Available from: http://www.depkes.go.id/index. php? vw=2 \&id=840.

5. Kaneshiro NK. Ear infection - acute images: Ear anatomy. c2010. Adam, Inc. [Cited 2015 Oct 9]. Available from: http: //www.healthline.com/ima ,yes/adam/ bisz/1092.jpg.

6. Ballengger JJ. Diseases of the Nose, Throat, Ear, Neck (13th ed). Iskandar HN, Mangunkusumo HE, Roesin HA, editors. Aswapi H, Roezin HA, Soetjipto HD, alih bahasa. Penyakit Telinga, Hidung, Tenggorok, Kepala dan Leher. Jakarta: Binapura Aksara, 1997; p. 101-7.

7. Anson BJ, editor. Morris' Human Anatomy 
Korompis, Tumbel, Mengko: Kesehatan telinga di Sekolah Dasar Negeri 11 ...

(12th ed), Part II Chapter X. New York: McGraw-Hill, 1996.

8. Anson BJ, Bast TH. In: Schenck HP, editor.
The Ear and Temporal Bone in Otolaryngology Vol. I Chapter I. Hagerstown: Prior, 1995. 